\title{
Determination of Some Stand and Site Parameters Influencing the Snow Damage in Trees: A Case Study of Boyabat Forest Enterprise, Turkey
}

\author{
Arif Oguz ALTUNELD
}

Kastamonu University, Faculty of Forestry, Department of Forest Engineering, Kastamonu, TURKEY aoaltunel@kastamonu.edu.tr

Received Date: 07.01.2019

Accepted Date: 12.02 .2019

\section{Abstract}

Aim of Study: Determination of the snow damage triggering stand and site parameter on trees.

Area of Study: Damaged compartments of Yedicam and Burnuk Forest Directorates, \#234 and \#116, within Boyabat Forest Enterprise of Kastamonu Regional Directorate of Forestry.

Material and Method: Two damaged and two control compartments from each directorate were compared to find if any site or stand parameters are related to the snow damage occurred in the area during 2014-2015 winter. Statistical analysis were carried out to test the significance of the parameters.

Main results: Age, relative density, the number of trees, basal area and stand volume of the stand parameters, and slope, site class, terrain roughness and soil depth of the site parameters were statistically linked to the snow damage.

Research highlights: The climate is a force to be reckoned with. New strategies must be devised and put into action in forest management. Studies have shown the mishaps. The lessons should be taken from the past experiences. Apparent mistakes must gradually be eliminated.

Keywords: Snow damage, stand parameters, site parameters

\section{Ağaçlarda Kar Zararını Etkileyen Bazı Meşcere ve Yetişme Ortamı Değişkenlerinin Tespiti: Boyabat Orman Işletme Müdürlüğü Örneği, \\ Türkiye}

Öz

Çalışmanın amacı: Ağaçlarda meydana gelen kar zararına etki eden meşcere ve yetişme ortamı değişkenlerinin tespit edilmesi.

Çalışma alanı: Kastamonu Orman Bölge Müdürlüğü’ne bağlı Boyabat Orman İşletme Müdürlüğü’nün Yediçam ve Bürnük İşletme Şefliklerinde kar zararının tespit edildiği 234 ve 116 numaralı bölmeler.

Meteryal ve Metod: 2014-2015 kış ve erken ilkbahar süresince kar zararı tespit edilen iki bölme, aynı meşcere ve yetişme ortamı özelliklerine haiz ancak zarar görmemiş, kontrol maksatlı seçilen iki bölme ile karşılaştırıldı, istatistiksel analizler yürütüldü.

Sonuçlar: Yaş, ağaç sıklığı, ağaç sayısı, meşcere göğüs yüzeyi ve hacmi gibi meşcere parametrelerine ilaveten, eğim, bonited, engebelilik ve toprak derinliği gibi mevki parametrelerinin, kar zararı üzerinde etkili oldukları tespit edildi.

Dikkat edilmesi gereken hususlar: İklim göz ardı edilmemesi gereken bir gerçektir. Bu doğrultuda, sıkıntıların bertaraf edilebilmesi için, yeni yönetimsel tercihler, gerekli görülen yerlerde uygulamaya alınmalıdır. Çalışmalar, aksi durumlarda karşılaşılabilecekleri göstermektedir. Geçmişte yaşananlardan dersler çıkarılmalı, yanlış uygulamalar tekrarlanmamslıdır.

Anahtar kelimeler: Kar zararı, meşcere parametreleri, saha parametreleri

\section{Introduction}

Natural or plantation with whatever approach have been administered to set up, Turkish forests are managed, depending upon the experience assembled during the last 150 years. Although the timber production seems to be leading agenda, the ecologic as well as the socio-cultural sensitivities are also looked after thus the management related strategies are shaped and varied. This way, the forests 
are maintained, periodically tended, protected and made sure that they reach the end of their planned rotation age when the optimum earnings are guaranteed (Nguyen and Nghiem, 2016). Such forests parts also called as the stands are renewed by the new generations growing underneath as they mature, so the cycle keeps on going by sticking to the principles of sustainability. Rotation periods vary between 50-60 and $100-120$ years in fast and slow growing tree species, respectively. When the vigor of the trees or the stands are prematurely hampered due to some unexpected phenomenon, predominantly economic as well ecologic and socio-cultural repercussions follow. Fire, storm, snow, insect and disease can be regarded as such. Above all, Kastamonu Regional Directorate Forestry (KRDF) experienced one such disaster in the form of an early spring windstorm in March 2013. The damage alone resulted in $1580000 \mathrm{~m}^{3}$ of timber loss spread around a large geography within the directorate. Lesser in frequency and extend, snow is another factor affecting the liveliness of the trees and stands. It is impossible to list the leading factors exacerbating the results of heavy snow-loads on tress, however, there are published studies elaborating the relationships between the snow-load and the tree and stand characteristics, topographic and soil factors, silvicultural tending prescriptions, etc.

Snow damage has long been the subject of numerous studies looking into its effects on the forests. Especially in Scandinavian countries, the US, Canada and other countries having mountain forests, heavy snow cause considerable damage on the forests (Hanewinkel, Breidenbach, Neeff, \& Kublin, 2008). In the continental Europe, 4 million $\mathrm{m}^{3}$ of annual timber loss are associated with the snow damage (Nykanen, Peltola, Quine, Kellomaki \& Broadgate, 1997). The aging, also know as the mature forest structuring accounted to be one of the major factors behind various damage types (Spathelf, Maaten, Maaten-Theunissen, Campioli \& Dobrowolska, 2014). Additionally, the damaged trees/forests were reported to be more susceptible to insect and fungus infestations (Schreoder and Lindelow, 2002). Strong winds are usually considered as the leading cause worsening the outcome of heavy snow (Petty and Worrell, 1981). However their role can be different. On one hand they can disperse the snow accumulated on trees (Solantie, 1994) and on the other they can freeze the already accumulated snow by further worsening the additional load on them, which could lead to uprooting, breaking or bending (Peltola, Nykanen \& Kellomaki, 1997). The geographical locations of the lands on which the forests reside, and the lands' topographical structuring (terrain roughness) are also the critical factors affecting the degree of abiotic damage factors on trees (Gardiner and Quine, 2000). Forests residing on the coastal and mid to high elevated terrains are generally hard hit from the snow loads because snow tends to accumulated on tree branches and canopies (Zhu et al., 2006). It can be said that the slope gradient has not been found as relevant as once thought, and the aspect has not been fully studied to establish a definitive relationship. Tree stem form and the canopy structuring were reported to be the leading factors defining the survivability of a tree. Asymmetric stem and canopy, and perpendicular branching are reported as tree characteristics increasing the snow damage risk (Valinger and Fridman, 1997). However, it must be noted that those are typical attributes of competition-free growing. Management related silvicultural prescriptions on the other hand, can be considered as interventions negatively or positively affecting the results of possible risks. The snow damage in stand level, does not only concern the timber losses or quality, but also forces the forest administration to apply not-projected salvage operations, and to deviate from the management plan dictated targets. The stands' stabilities against the snow and the wind were reported to be related to the basal area in hectare (ha), the trees' spacing and slenderness ratios (Martin_Alcon, G-Olabarria \& Coll, 2010; Castedo-Dorado, Crecente-Campo, AlvarezAlvarez \& Barrio-Anta, 2009; Wang, Tits \& LeMay, 1998). Heavy timber losses were observed especially on the thinned edges of Scots pine forests when the snow loads were further increased by strong winds (Peltola, 1996). Besides, in places where the trees 
could not well anchor themselves to the ground - i. e., shallow soil depth or extreme slope, extensive damage resulting from either wind or snow in individual trees was observed (Zubizarreta-Gerendiain, Pellikka, Garcia-Gonzalo, Ikonen \& Peltola, 2012). The snow accumulations appeared to be concentrated in the stands' interiors where even under light snow, Scots pines with low slenderness ratios, were seriously damaged (Pellika and Jarvenpaa, 2003). Although short in height, the trees with large diameter at breast height (dbh) were more subjected to branch or stem breakages rather than uprooting (Peltola, Kellomaki, Hasinen \& Granander, 2000). During the planned rotation cycles, if the level of intermittent silvicultural or management related interventions was inadvertently exaggerated in some parts of the stands, it was observed that in the following years, the possibility of those parts to be adversely affected from the snow raised considerably (Fridman and Valinger, 1998). The snow damage is a phenomenon faced in anytime, depending upon the severity of the winter and precipitation regimes in the Turkish forests. Since it has long been experienced as sporadic occurrences here and there, no particular attention has been given to find the underlining causes. The snow damages investigated in this study occurred extensively in two forest sub-compartments of Yedicam and Burnuk forest directorates in Boyabat Forest Enterprise (BFE) within KRDF during the winter of 2014-2015.

It was the objective of this particular study to find if the stand and site characteristics triggering the snow damage here but not there vary within these parameters.

\section{Material and Methods \\ Study Area}

The study was conducted in two forest directorates of the BFE, Turkey. Two compartments, 234 and 116 of the forest directorates, Yedicam and Burnuk, which registered unusually extensive snow damage during the winter of 2014-2015 were selected for this study (Yellow dots inside the directorates of BFE in Figure 1). BFE is one of five such administrative units within the former Sinop Regional Directorate of Forestry (SRDF). Since the October, 2011, SRDF has become part of the neighboring KRDF. The heavily forested geography has a standing volume of 195 million (mil) $\mathrm{m}^{3}$ and an approximate annual increment of $5.7 \mathrm{mil}$ $\mathrm{m}^{3}$. $2054000 \mathrm{~m}^{3}$ of industrial timber was produced in 2017, and BFE's contribution was $137000 \mathrm{~m}^{3}$. The pure and mixed stands including species such as Fir (Abies nordmanniana subsp. equi-trojani), Scots pine (Pinus sylvestris), Corsican pine (Pinus nigra), Red pine (Pinus brutia), Beech (Fagus orientalis) and Juniper (Juniperus communis) form the forests of BFE. Topography is rather treacherously broken inside the Isfendiyar and east Ilgaz mountain chains; there are riverbeds, occasional level plains and high plateaus. The characteristics of the terrestrial climate reign all over the enterprise with hot summers and cold winters. Precipitation in the form of rain is concentrated around the spring months; the number of average annual rainy/snowy days is 80 , and the amount of average annual precipitation varies between $300-500 \mathrm{~mm}$. 


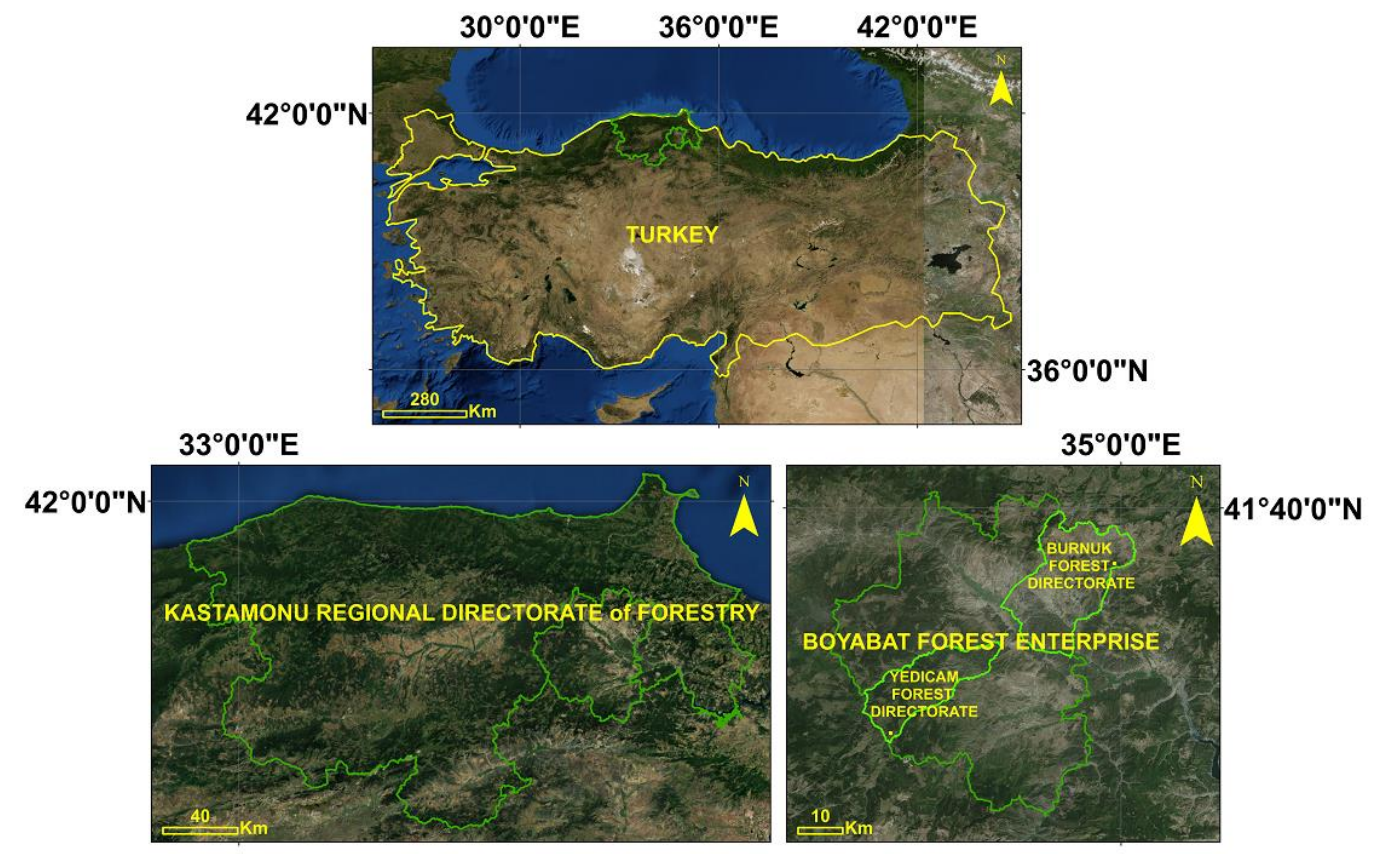

Figure 1. Location of the study area

\section{Material and Methodology}

This study was realized, depending upon the data collected from four compartments of BFE. One seriously damaged compartment from both Yedicam and Burnuk forest directorates was compared to a similarly conditioned and structured control compartment in the respected directorate. Thirty $800 \mathrm{~m}^{2}$ circular sample plots were randomly selected from each compartment, and the following parameters were measured and computed;

- Quadratic mean diameter $\left(d_{q}, \mathrm{~cm}\right)$, was calculated for each sample plot after the diameter at breast height $(d b h, \mathrm{~cm})$ had been measured for all the trees included within the sample plots,

- Stand age ( $t$, year) was determined through the averaging of number of tree rings from increment cores acquired from eight to ten trees within the sample plots,

- For each sample plot, aspect, slope, elevation and terrain roughness values were extracted from digital elevation model(s) (Altunel, 2018) - i. e. flat, east, west, north, south; 0-10\% (1), 10-30\% (2), $>30 \%$ (3); 1000-1200m (1), 1200-1400m (2) and less rough (1), rough (2) more rough (3), respectively. Terrain roughness was calculated as a function of the slope.
The digital elevation models constructed for four compartments (2 damaged, 2 control) were first converted to slope models. Rasterized slope models composed of a number of neighboring cells assigned with a slope value. Every cell within the model was compared to its surrounding 8 cells. The variability within these 9 cells was the roughness value for the cell in question. If all the slope values across the 9 cells matched, the particular cell got the roughness value as 1 . The more the variability within the questioned cells, the higher the terrain roughness (Riley, DeGloria \& Elliot, 1999). Although a direct connection linking this particular parameter to the damage could not be established through the recent literature, the successful previous studies were convincing enough to evaluate it as a possible factor (Hanna, 1981). Thus, a nine class terrain roughness map was first produced, it was then consolidated into 3 classes for the analysis.

- The number of trees (N/ha), basal area $\left(\mathrm{m}^{2} / \mathrm{ha}\right)$ and stand volume $\left(\mathrm{m}^{3} / \mathrm{ha}\right)$ were calculated through the sample plots,

- Soil depth(s) and major soil type(s) (MST) were extracted from the vectorized provincial soil classification maps - i.e. 0$30 \mathrm{~cm}$ (1), $30-50 \mathrm{~cm}(2),>50 \mathrm{~cm}$ (3) and brown forest soil, cambisol, which had a 
certain emphasize on silt (M) and on gravel (G),

- Relative stand density $(R D)$ was determined according to Curtis, Clendenan \& Demars (1981),

- Site class (absolute), crown closure, and age class (for cross validation with increment cores) were determined through the databases pertaining to the current forest management plans $-\mathrm{i}$. e. best (1), good (2), fair (3), bad (4); 40-70\% and $>70 \%$, and 40-60 years, 60-80 years and $>80$ years, respectively,

- In the plots including both the damaged and not-damaged trees, the ratios of the number of damaged trees, their basal areas and volumes in comparison to the overall number of trees, their basal areas and volumes were separately computed.

Kolmogorov-Smirnov test was applied to assess the normality of the quadratic mean diameter, stand age, relative density, the number of trees, basal area and volume computed for the sample plots, as well as the proportional damage ratios with regard to the number of trees, basal area and stand volume. The test confirmed that the latter mentioned damage ratios did not manifest normal distribution $(\mathrm{p}<0.05)$, whereas the others did $(\mathrm{p}>0.05)$. Student's t-test was used to assess if a significant difference was present between the damaged and control plots in terms of the quadratic mean diameter stand age, relative density, the number of trees, basal area and volume. Additionally, Spearman Correlation test was utilized to determine if there was any correlation between the proportional damage ratios of the computed parameters. Finally, Chi-square test was used to evaluate the distribution of the site parameters - i. e. aspect, slope, roughness, elevation, site class, crown closure and age class across the damaged and control plots. ArcGIS 10.3 and IBM SPSS Statistics 23 software were used for the analysis.

\section{Results}

The means of the stand age, relative density, number of trees, stand basal area and stand volume were significantly different between the damage and the control groups, however mean diameter did not register any difference because it was almost the same in both the damaged and control groups (Table $1)$.

Table 1. Comparisons between snow damage groups for stand parameters

\begin{tabular}{lccc}
\hline Stand parameter & Damaged $(\mathrm{n}=36)$ & Control $(\mathrm{n}=84)$ & $p$ \\
\hline Mean diameter $\left(d_{q}, \mathrm{~cm}\right)$ & $28.8( \pm 3.7)^{\mathrm{a}}$ & $27.6( \pm 3.1)$ & $0.073^{\mathrm{ns}}$ \\
\hline Stand age $(t$, year$)$ & $82.1( \pm 7.2)$ & $68.9( \pm 19)$ & $<0.001^{*}$ \\
\hline Relative density $(R D)$ & $3.60( \pm 0.82)$ & $2.8( \pm 0.59)$ & $<0.001^{*}$ \\
\hline Number of trees $(\mathrm{N} / \mathrm{ha})$ & $294.6( \pm 63)$ & $246.3( \pm 38.6)$ & $<0.001^{*}$ \\
\hline Basal area $\left(\mathrm{m}^{2} / \mathrm{ha}\right)$ & $19.371( \pm 5.084)$ & $14.808( \pm 3.736)$ & $<0.001^{*}$ \\
\hline Stand volume $\left(\mathrm{m}^{3} / \mathrm{ha}\right)$ & $166.589( \pm 47.618)$ & $125.704( \pm 37.416)$ & $<0.001^{*}$ \\
\hline${ }^{\mathrm{a}}$ Mean $\left( \pm\right.$ Standard deviation) ${ }^{\text {ns }}{ }^{*}$ Non-significant at 0.05 level, ${ }^{*}$ Significant at 0.001 level.
\end{tabular}

The strongest correlation between the damage and the computed stand parameter was obvious in relative density ( $\mathrm{r} ; 0.507)$. Positive relationship between the older conifers and the damage was validated (Zeng et al., 2004) Although getting weaker, all the remaining stand parameters, which were the result of forest management related interventions, manifested some degree of positive correlation (Table 2). 
Table 2. Correlations between damage ratios and stand parameters

\begin{tabular}{lcccccc}
\hline Stand parameter & $\begin{array}{c}\text { Damage ratio for } \\
\text { the number of } \\
\text { trees }\end{array}$ & \multicolumn{2}{c}{$\begin{array}{c}\text { Damage ratio for } \\
\text { basal area }\end{array}$} & \multicolumn{2}{c}{$\begin{array}{c}\text { Damage ratio for } \\
\text { stand volume }\end{array}$} \\
\cline { 2 - 7 } & $r$ & $P$ & $r$ & $p$ & $r$ & $p$ \\
\hline Mean diameter $\left(d_{q}, \mathrm{~cm}\right)$ & 0.241 & $0.008^{* *}$ & 0.228 & $0.012^{*}$ & 0.226 & $0.013^{*}$ \\
\hline Stand age $(t$, year $)$ & 0.339 & $<0.001^{* * *}$ & 0.335 & $<0.001^{* * *}$ & 0.333 & $<0.001^{* * *}$ \\
\hline Relative density $(R D)$ & 0.507 & $<0.001^{* * *}$ & 0.514 & $<0.001^{* * *}$ & 0.512 & $<0.001^{* * *}$ \\
\hline Number of trees $(\mathrm{N} / \mathrm{ha})$ & 0.464 & $<0.001^{* * *}$ & 0.481 & $<0.001^{* * * *}$ & 0.482 & $<0.001^{* * *}$ \\
\hline Basal area $\left(\mathrm{m}^{2} / \mathrm{ha}\right)$ & 0.479 & $<0.001^{* * *}$ & 0.482 & $<0.001^{* * *}$ & 0.481 & $<0.001^{* * *}$ \\
\hline Stand volume $\left(\mathrm{m}^{3} / \mathrm{ha}\right)$ & 0.458 & $<0.001^{* * *}$ & 0.458 & $<0.001^{* * *}$ & 0.456 & $<0.001^{* * *}$ \\
\hline
\end{tabular}

${ }^{*}$ Significant at 0.05 level, ${ }^{* *}$ Significant at 0.01 level, ${ }^{* * *}$ Significant at 0.001 level.

In Table 3, slope appeared to be a rather significant factor in the occurrence of snow damage. The results showed the snow damage considerably increased as the slope gradient got bigger. The age class showed the same tendency. As the stands got mature, the snow damage risk grew simultaneously. Four distinct site classes were present across the sample plots, and the analysis results showed as the site classes deteriorated, the snow damage risk increased. The crown closure was another site parameter showing relationship with the snow damage. However, there were only two classes 40$70 \%$ and $>70 \%$ for comparison, and not enough sample point coincided with the first class to come up with a definitive result to claim this relationship as a fact. Additionally, positive correlation of all stand parameters in terms of the snow damage ratios in Table 2 with respect to the number of trees, basal area and stand volume was also nullifying such an inference. The soil depth was also showing strong relationship with the snow damage. Apparently, as the tree roots found enough soil depth to anchor the above tree mass to the ground firmly, they could better withstand the climatic anomalies. Interestingly, terrain roughness also showed significance in terms of snow damage. The results confirmed that as the terrain roughness registered bigger, the snow damage risk also rose. 
Table 3. Comparisons between snow damage groups for site parameters

\begin{tabular}{|c|c|c|c|c|}
\hline Site parameter & Class & Damaged $(n=36)$ & Control $(n=84)$ & $p$ \\
\hline \multirow[t]{5}{*}{ Aspect } & Flat $(n=15)$ & $3(20 \%)$ & $12(80 \%)$ & $0.323^{\mathrm{ns}}$ \\
\hline & North $(n=44)$ & $15(34.1 \%)$ & $29(65.9 \%)$ & \\
\hline & East $(n=38)$ & $8(21.1 \%)$ & $30(78.9 \%)$ & \\
\hline & South $(n=3)$ & $1(33.3 \%)$ & $2(66.7 \%)$ & \\
\hline & West $(n=20)$ & $9(45 \%)$ & $11(55 \%)$ & \\
\hline \multirow[t]{3}{*}{ Slope } & $0-10 \%(n=24)$ & $4(16.7 \%)$ & $20(83.3 \%)$ & $0.003^{* *}$ \\
\hline & $10-30 \%(\mathrm{n}=59)$ & $13(22 \%)$ & $46(78 \%)$ & \\
\hline & $>30 \%(\mathrm{n}=37)$ & $19(51.4 \%)$ & $18(48.6 \%)$ & \\
\hline \multirow[t]{2}{*}{ Elevation } & $<1200 m(n=40)$ & $8(20 \%)$ & $32(80 \%)$ & $0.091^{\mathrm{ns}}$ \\
\hline & $>1200 \mathrm{~m}(\mathrm{n}=80)$ & $28(35 \%)$ & $52(65 \%)$ & \\
\hline \multirow[t]{3}{*}{ Age class } & $40-60$ years $(n=32)$ & $1(3.1 \%)$ & $31(96.9 \%)$ & $0.001^{* *}$ \\
\hline & $60-80$ years $(n=52)$ & $20(38.5 \%)$ & $32(61.5 \%)$ & \\
\hline & $>80$ years $(n=36)$ & $15(41.7 \%)$ & $21(58.3 \%)$ & \\
\hline \multirow[t]{4}{*}{ Site class } & $1(\mathrm{n}=3)$ & $0(0 \%)$ & $3(100 \%)$ & $0.006^{* *}$ \\
\hline & $2(n=19)$ & $0(0 \%)$ & $19(100 \%)$ & \\
\hline & $3(n=88)$ & $31(35.2 \%)$ & $57(64.8 \%)$ & \\
\hline & $4(n=10)$ & $5(50 \%)$ & $5(50 \%)$ & \\
\hline \multirow[t]{2}{*}{ Crown closure } & $40-70 \%(n=10)$ & $6(60 \%)$ & $4(40 \%)$ & $0.031^{*}$ \\
\hline & $>70 \%(\mathrm{n}=110)$ & $30(27.3 \%)$ & $80(72.7 \%)$ & \\
\hline \multirow{3}{*}{$\begin{array}{l}\text { Terrain } \\
\text { roughness }\end{array}$} & $1(n=34)$ & $6(17.6 \%)$ & $28(82.4 \%)$ & $0.043^{*}$ \\
\hline & $2(n=53)$ & $15(28.3 \%)$ & $38(71.7 \%)$ & \\
\hline & $3(n=33)$ & $15(45.5 \%)$ & $18(54.5 \%)$ & \\
\hline \multirow[t]{3}{*}{ Soil depth } & $0-30 \mathrm{~cm}(\mathrm{n}=30)$ & $19(63.3 \%)$ & $11(36.7 \%)$ & $<0.001^{\text {**** }}$ \\
\hline & $30-50 \mathrm{~cm}(\mathrm{n}=60)$ & $17(28.3 \%)$ & $43(71.7 \%)$ & \\
\hline & $>50 \mathrm{~cm}(\mathrm{n}=30)$ & $0(0 \%)$ & $30(100 \%)$ & \\
\hline \multirow[t]{2}{*}{ MST } & $M(n=60)$ & $19(31.7 \%)$ & $41(68.3 \%)$ & $0.690^{\mathrm{ns}}$ \\
\hline & $\mathrm{G}(\mathrm{n}=60)$ & $17(28.3 \%)$ & $43(71.7 \%)$ & \\
\hline
\end{tabular}

${ }^{*}$ Significant at 0.05 level, ${ }^{* *}$ Significant at 0.01 level, ${ }^{* * *}$ Significant at 0.001 level,

${ }^{\text {ns }}$ Non-significant at 0.05 level.

\section{Discussion and Conclusion}

The Black sea region of Turkey can unquestionably be regarded as the Mecca of the forests in the country. It is further emphasized within the Western part of the region. In terms of the acreage, growing stock, annual increment and production, the region including the provinces of Kastamonu, Zonguldak and Bolu, along with their namesake regional forest directorates, produces a considerable amount of the country's timber need. The natural characteristics are suitable for tree growth in this region, however the effects of climate change have started to unprecedentedly change the dynamics even in forestry sector (Tayanc, Im, Dogruel \& Karaca, 2009; Ozcan, Musaoglu \& Turkes, 2018). The never before seen forest fires have started to hit the region, and the strategies are devised to cope with the problem (Kucuk, Topaloglu, Altunel \& Cetin, 2017). KRDF was ravaged by a wind-storm in March 2013, causing 1.5 million $\mathrm{m}^{3}$ timber loss (Torun, 2018). The objective of this particular study, the snow damage is a phenomenon frequently seen in sporadic occurrences during the winter and early spring in the region. Type of the damage has long been so coincidental that no study has so far looked into the underlying reasons. On the other hand, the extent of the damage analyzed in BFE was rather extensive and concentrated to deserve a comprehensive study. The most active and prevalent method of lessoning the damage caused by the wind and snow on forests is to avoid the silvicultural and management related practices which have been proven to adversely affect the outcome. It was recommended that the stands reaching the 
critical stages should be strategically managed (Hirvela and Hynynen, 1990). Slope, site class, terrain roughness and soil depth were the site parameters which were found as statistically significant factors in the definition of snow damage in this study, however aspect, elevation and major soil type were not. The nature of the damage was already pointing the slope as one possible factor because the damage was concentrating on slopes in both damaged compartments (Figure 2). Although the past studies showed that both the slope and the aspect were found rather less related and inconclusive (Nykanen et al. 1997) as factors influencing snow damage on trees, they can still be considered as important on soil fertility (Scholten et al., 2017) and morphology (Valtera, Samonil, Svoboda \& Janda, 2015). Since these are crucial factors on tree growth, slope might very well be a decisive parameter negatively affecting the proper formation of such factors. Slope and aspect were extracted from digital elevation models. They were categorized into individual classes, for ease of convenience and evaluation. The statistical analysis showed one as an important topographical parameter among the snow damage triggering factors, however, it is very obvious that there are apparently much more to this conclusion than referring the slope as a percent figure.
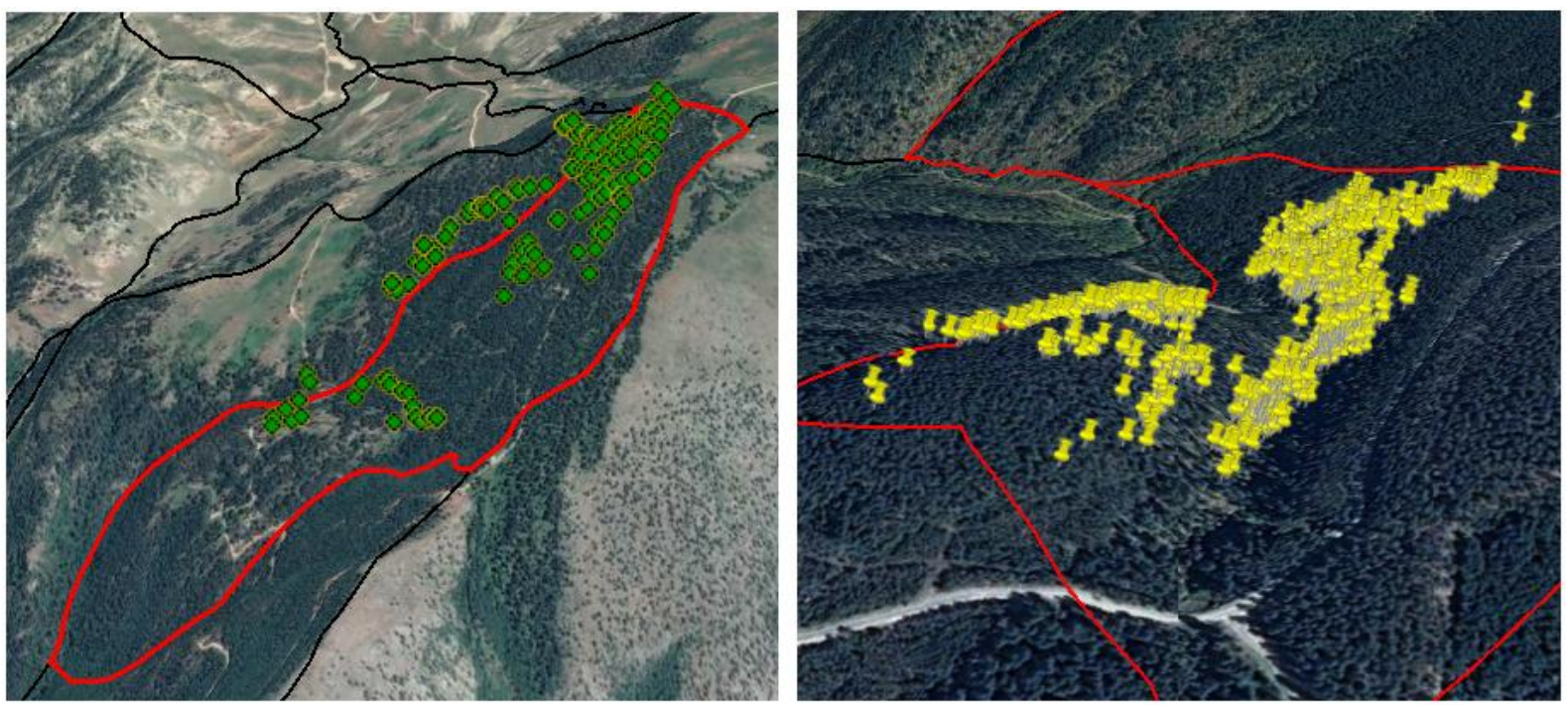

Figure 2. The locations of the snow damaged trees in compartments, 116 and 234

Soil formation, preservation and fertility get worsen as the percentage of the slope increases (Fang, Sun \& Tang, 2014). Not enough soil leads to poor site class and soil depth. Besides, if the topography is treacherous increasing the terrain roughness, the ground becomes not-ideal to support the trees because soil fertility was drastically influenced by the topographical factors (Scholten et al., 2017). Despite these adversities, as long as the climatic conditions progresses favorable, trees can still grow just fine until the unexpected occurs. Snow is one such anomaly adding considerable weight over trees which have precariously anchored to the soil (Zubizarreta-Gerendiain et al., 2012).

Although reported as snow damage, it was not clear if the damage occurred purely based upon the snow accumulation or an unexpected strong wind accompanied it, making the damage even greater. Trees growing regimes shapes around the prevailing climatic conditions, so they develop strength to those conditions. Other than the above mentioned sporadic occurrences, no previous extensive snow damage record existed either in the directories or in the enterprise. As the climate change is considered, it is rather unlikely that a similar damage would repeat itself in the 
future. However, when unexpected anomalies throw conditions which the trees and forests are not accustomed to, then such phenomenon would continue to take place in our forests. It is not known what kind of silvicultural or management related treatments were applied to these stands in the past. The tending prescriptions can positively as well as negatively change the risks through the preferences of regeneration, thinning and rotation (Nykanen et al., 1997). The stand characteristics are all related to the management strategies in Turkey because all the forests and forest lands are managed through forest management plans. Six stand parameters were computed through field data collected in both the damaged and the control compartments. Student's t-test showed that the stand age, relative density, the number of trees, basal area and stand volume figures were found significantly different in the damaged compartments compared to the control ones $(p<0.001)$. Mean diameter, $d_{q}$, was not found significant as a stand parameter because in both the damaged and the control groups, it was almost the same. However, dbh which is a factor in the calculation of $d_{q}$ in single tree evaluation is so important as a factor in tree taper or slenderness ratio (Diaz-Yanez, MolaYudego, Gonzalez-Olabarria \& Pukkala, 2017) that further study would certainly have the potential to yield viable results. Then, these parameters' involvement in the damage was checked through Spearman's correlation test in terms of the number of damaged trees, basal area and stand volume. All the evaluated stand parameters were significant, varying in level. The thinning procedures are implemented as selective rather than systematic in Turkey. It is the main intervention behind the calculated stand parameters in this study. Thinning is a must in forestry if the ideal bole form, good anchoring attributes and aeration through the stands would be met (Cameron, 2002). However, it changes the relative density, the number of trees, , basal area and stand volume in any given area and leaves the stands vulnerable to wind and snow damage (Pellika and Jarvenpaa, 2003; Martin_Alcon et al., 2010). It would take very many years for a stand to compensate for the degree of intervention and to regain its stability. During this period, if a climatic anomaly hits the stand(s), it is very likely that they would suffer in unusual levels. All the compartments, damaged and control, have long been managed in BFE, but it is not clear if the past interventions were excessive in the damaged compartments, but ideal in the control ones.

Both stand; age, relative density, the number of trees, basal area and volume and site; slope, site class, terrain roughness and soil depth, parameters were found as decisive factors in the evaluation of snow damage on forest stands. Site is not a medium which can be drastically altered for the forest growth, it involves topographic and climatic derivatives. The living organisms prefer that site because their capabilities suit well to the region. However, the mentioned stand parameters are always changed as the management strategies dictate. Today, forests are so intertwined with the management decisions and activities that accidentally changing one parameter automatically affects the other(s), leaving the stands vulnerable to climatic anomalies. This study and many others showed the factors affecting the stability of forest stands against such uncertainties, snow in this case. Forests will grow and produce tangible goods for the mankind, and we will intervene that cycle with the knowledge and know-how to make it even better. Unfortunately, there are forces which we would probably never harness, thus research outputs like this should be taken seriously to see what we are up against in the management of the forests.

\section{Acknowledgment}

I thank my dear friend and colleague Oytun Emre SAKICI, $\mathrm{PhD}$ for his unconditional support and mentoring in shaping this paper. Additionally, I thank state engineer Abdullah KAPUCU for his dedication to the profession, tenacious field work and dependable data coverage. The making of this paper is the culmination of a research project, KUBAP-01/2015-29, funded by the coordinator-ship of scientific research funds of Kastamonu University. 


\section{References}

Altunel, A.O. (2018). Suitability of open-access elevation models for micro-scale watershed planning, Environmental Monitoring and Assessment, 190:512, doi.org/10.1007/s10661 -018-6890-1.

Cameron, A.D. (2002). Importance of early selective thinning in the development of longterm stand stability and improved log quality: a review, Forestry, 75(1), 25-35.

Castedo-Dorado, F., Crecente-Campo, F., Alvarez-Alvarez, P. \& Barrio-Anta, M. (2009). Development of a stand density management diagram for radiata pine stands including assessment of stand stability, Forestry, $82(1), \quad$ doi: 10.1093/forestry/cpm032.

Curtis, R.O., Clendenan, G.W. \& Demars, D.J. (1981). A new stand simulator for coast Douglas-fir: DFSIM user's guide. USDA Forest Service General Technical Report PNW-1128. Pasific Northwest Forest and Range Experiment Station, Portlan, Oregon, USA.

Diaz-Yanez, O., Mola-Yudego, B., GonzalezOlabarria, J.R. \& Pukkala, T. (2017). How does forest composition and structure affect the stability against wind and storm?, Forest Ecology and Management, 401, 215-222.

Fang, H., Sun, L. \& Tang, Z. (2014). Effects of rainfall and slope on runoff, soil erosion and rill development: an experimental study using two loess soils, Hydrological Processes, 29, 2640-2658.

Fridman, J. \& Valinger, E. (1998). Modelling probability of snow and wind damage using, tree, stand and site characteristics from Pinus sylvestris sample plots, Scandinavian Journal of Forest Research, 13(1-4), 348-356.

Gardiner, B.A. \& Quine, C.P. (2000). Management of forests to reduce the risk of abiotic damage - a review with particular reference to the effects of strong winds, Forest ecology and Management, 135, 261277.

Hanewinkel, M., Breidenbach, J., Neeff, T. \& Kublin, E. (2008). Seventy-seven years of natural disturbances in a mountain forest area - the influence of storm, snow, and insect damage analysed with a long-term time series, Canadian Journal of Forest Research, 38(8), 2249-2261.

Hanna, S.R. (1981). Diurnal variation of horizontal wind direction fluctions in complex terrain at Geyserc, Cal., Boundary-Layer Meteorology, 21(2), 207-213.

Hirvela, H. \& Hynynen, J. (1990). Effect of fertilization on the growth, top damage and susceptibility to windthrow of Scots pine stands in Lapland, Folia Forestalia, Finnish Forest Research Institute, 764, 16.

Kucuk, O., Topaloglu, O., Altunel, A.O. \& Cetin, M. (2017). Visibility analysis of fire lookout towers in the Boyabat State Forest Enterprise in Turkey, Environmental Monitoring and Assessment, 189:329, doi.org/10.1007/s10661 -017-6008-1.

Martin-Alcon, S., G-Olabarria, J.R. \& Coll, L. (2010). Wind and Snow Damage in the Pyrenees Pine Forests: Effect of Stand Attributes and Location, Silva Fennica, 44(3), 399-410.

Nguyen, T.T. \& Ngheim, N. (2016). Optimal forest rotation for carbon sequestration and biodiversity conservation by farm income levels, Forest Policy and Economics, 73, 185194.

Nykanen, M-L, Peltola, H., Quine, C., Kellomaki, S. \& Broadgate, M. (1997). Factors affecting snow damage of trees with particular reference to European conditions, Silva Fennica, 31(2), 193-213.

Ozcan, O., Musaoglu, N. \& Turkes, M. (2018). Assessing vulnerability of a forest ecosystem to climate change and variability in the western Mediterranean sub-region of Turkey, Journal of Forest Research, 29(3), 709-725.

Pellika, P. \& Jarvenpaa, E. (2003). Forest Stand Charecteristics and Wind and Snow Induced Forest Damage in Boreal Forest, Proceeding of the International Conference on "Wind Effects on Trees", 269-276, Karlsruhe, Germany, 16-18 September, 2003.

Peltola, H. (1996). Swaying of trees in response to wind and thinning in a stand of Scots pine. Boundary-Layer Meteorology, 77(3-4), 285304.

Peltola, H., Kellomaki, S., Hasinen, A. \& Granander, M. (2000). Mechanical stability of Scots pine, Norway spruce and birch: an analysis of tree-pulling experiments in Finland. Forest Ecology and Management, 135, 143-153.

Peltola, H., Nykanen, M-L. \& Kellomaki, S. (1997). Model computations on the critical combination of snow loading and windspead for snow damage of scots pine, Norway spruce and Birch sp. at stand edge. Forest Ecology and Management, 95, 229-241.

Petty, J.A. \& Worrell, R. (1981). Stability of Coniferous Tree Stems in Relation to Damage 
by Snow. Forestry: An International Journal of Forest Research, 54(2), 115-128.

Riley, S.J., DeGloria, S.D. \& Elliot, R. (1999). A Terrain Index That Quantifies Topogrphic Heterogeneity, Intermountain Journal of Science, 5(1-4), 23-27.

Scholten et al. (2017). On the combined effect of soil fertility and topography on tree growth in subtropical forest ecosystems - a study from SE China, Journal of Plant Ecology, 10(1): 111-127, doi:10.1093/jpe/rtw065.

Schroeder, L.M. \& Lindelow, A. (2002). Attacks on living spruce trees by the baark beetle Ips typographus (Col. Scolytidae) following a strom-felling: a comparison between stands with and without removal of wind-felled trees, Agricultural and Forest Entomology, 4, 4756.

Solantie, R. (1994). Effect of Weather and Climatological Background on Snow Damage of Forests in Southern Finland in November 1991, Silva Fennica, 28(3), 203-211.

Spathelf, P., Maaten, E. van der., Maaten_Theunissen M. van der., Campioli, M. \& Dobrowolska, D. (2014). Climate Change impact in European forests: the expert views of local observers, Annals of Forest Science, 71, 131-137.

Tayanc, M., Im, U., Dogruel, M \&, Karaca, M. (2009). Climate Change in Turkey fort he last half century, Climate Change, 94(3-4), 483502.

Torun, P. (2018). Modelling of Windstorm damage on Kastamonu Forests Using Maximum Entropy Methodology, Unpublished Msc. Thesis, Kastamonu University, Kastamonu, Turkey, in Turkish, $112 \mathrm{p}$.

Valinger, E. \& Fridman, J. (1997). Modelling probability of snow and wind damage in Scots pine stands using tree characteristics, Forest Ecology and Management, 97, 215-222.

Valtera, M., Samonil, P., Svoboda, M. \& Janda. (2015). Effects of topography and forest stand dynamics on soilmorphology in three natural Picea abiesmountain forests, Plant Soil, 392, 57-69.

Wang, Y., Tits, S.J. \& LeMay, V.M. (1998). Relationships between tree slenderness coefficients and tree or stand characteristics for major species in boreal mixedwood forests, Canadian Journal of Forest Research, 28(8), 1171-1183.

Zeng, H., Peltola, H., Talkkari, A., Venalainen, A., Strandman, H., Kellomaki, S. \& Wang, K. (2004). Influence of clear-cutting on the risk of wind damage at the forest edges, Forest Ecology and Management, 203, 77-88.
Zhu, J-j., Li, X-f., Liu, Z-g., Cao W., Gonda, Y. \& Matsuzaki, T. (2006). Factors Affecting the Snow and Wind Induced Damage of a Montane Secondary Forest in Northestern China, Silva Fennica, 40(1), 37-51.

Zubizarreta-Gerendiain, A., Pellikka, P., GarciaGonzalo, J., Ikonen, V.P. \& Peltola, H.( 2012). Factors Affecting Wind and Snow Damage of Individual Trees in a Small Management Unit in Finland: Assessment Based on Inventoried Damage and Mechaniztic Modelling, Silva Fennica, 46(2), 181-196 